\title{
PENGARUH MOTIVASI BELAJAR DAN METODE PEMBELAJARAN TERHADAP PRESTASI BELAJAR MAHASISWA PROGRAM STUDI KOMPUTERISASI AKUNTASI POLITEKNIK LP3I JAKARTA KAMPUS BLOK M"
}

\author{
Asmawi Mangku Alam \\ Politeknik LP3I Jakarta \\ asmawi@lp3i.ac.id
}

\begin{abstract}
Abstrak. Penelitian ini diangkat dari tesis yang bertujuan untuk menganalisis seberapa besar Pengaruh Motivasi Belajar dan Metode Pembelajaran terhadap Prestasi Belajar Mahasiswa Program Studi Komputerisasi Akuntasi Politeknik LP3I Jakarta Kampus Blok M" Penelitian dilakukan karena diindikasikan bahwa mahasiswa prestasi belajar mahasiswa mengalami sedikit masalah dan itu diduga karena masih elmahnya motivasi dan metode pembelajaran yang dilakukakan oleh mahasiswa yang bersangkutan

Metode pengambilan sampel yang digunakan adalah Teknik pengambilan sample dilakukan sampling jenuh yaitu dengan mengambil 50 populasi semuanya sebagai sampel. Data-data yang telah memenuhi uji validitas dan uji reliabilitas selanjutnya diolah sehingga menghasilkan persamaan regresi $\mathrm{Y}=0,850+$ $0.645 \mathrm{X} 1+0.117 \mathrm{X} 2$, dimana dimana $\mathrm{Y}$ adalah variabel prestasi belajar, $\mathrm{X} 1$ adalah variabel motivasi belajar dan X2 adalah variabel metode pembelajaran

Motivasi belajar secara parsial berpengaruh positif terhadap prestasi belajar yang ditunjukkan oleh nilai $\mathrm{r}$ sebesar 0.682 yang berarti hubungan diantara keduanya kuat. Metode pembelajaran secara parsial berpengaruh positif terhadap prestasi belajar yang ditunjukkan oleh nilai $\mathrm{r}$ sebesar 0,458 yang berarti hubungan diantara keduanya sangat kuat. Secara simultan variabel kemampuan pengajar dan media pembelajaran memiliki pengaruh yang signifikan terhadap kepuasan warga belajar yang ditunjukkan oleh nilai $r$ sebesar 0,687 yang berarti hubungan diantara keduanya sangat kuat. Sedangkan nilai koefisien determinasi R square sebesar 0, 4719 yang artinya bahwa variasi dari semua variabel bebas yaitu motivasi belajar dan metode belajar dapat menerangkan variabel prestasi mahasiswa sebesar 47,19\%, sedangkan sisanya sebesar 52,81\% diterangkan oleh variabel lain yang tidak diajukan dalam penelitian ini.
\end{abstract}

Kata kunci : Motivasi belajar, metode pembelajaran, prestasi belajar, LP3i Jakarta Kampus Blok M, regresi linier berganda

Abstract. This study was taken from the thesis that aims to analyze how big Influence of Motivation and Learning Method of the Achievement of Student Learning Program Computerized Accounting Polytechnic LP3I Jakarta Campus Blok M "study was conducted that indicated that student achievement of students having a bit of trouble and it was suspected because they elmahnya motivation and learning methods dilakukakan by students concerned

The sampling method used is the technique of sampling Sampling saturated namely by taking them as a population of 50 samples. Data that has met the test of validity and reliability further processed to produce a regression equation $Y=0.850+0645+0117 X 2 X 1$, which wherein $Y$ is variable learning achievement, $X 1$ is a variable of learning motivation and $X 2$ is variable learning method

Motivation to learn is partially positive effect on learning achievement indicated by the $r$ value of 0.682, which means a strong relationship between them. The learning method is partially positive effect on learning achievement indicated by the $r$ value of 0.458 which means the relationship between them is very strong. Variables simultaneously teaching and learning media capabilities have a significant impact on the learning citizen satisfaction shown by the $r$ value of 0.687 which means the relationship between them is very strong. While the coefficient of determination $R$-square value of 0,4719 , which means that the variation of all the independent variables that motivation to learn and learning methods may explain the 
variable student achievement by $47.19 \%$, while the remaining $52.81 \%$ is explained by other variables that are not submitted within this research.

Key word : $\quad$ motivation to learn, learning methods and learning achievement, LP3i Jakarta Kampus Blok $M$, multiple linear regression

Pendidikan merupakan salah satu hal mendasar yang perlu memiliki kualitas yang baik dalam sebuah negara. Keberhasilan dunia pendidikan sendiri dipengaruhi oleh perubahan dan pembaharuan dalam segala unsur pendidikan. Unsur-unsur pendidikan tersebut diantaranya yaitu peserta didik, pendidik, alat dan metode, materi dan lingkungan pendidikan. Setiap unsur pendidikan yang ada semuanya saling terkait dalam mendukung tercapainya tujuan pendidikan.

Perkembangan pendidikan selalu mengalami perubahan seiring dengan kebutuhan dalam persaingan secara global. Hal ini menimbulkan tantangan dalam upaya menyiapkan sumber daya manusia yang berkualitas dan mampu bersaing pada setiap tantangan yang ada. Peningkatan sumber daya manusia dalam proses pendidikan melalui beberapa tahap atau jenjang pendidikan. Di Indonesia jenjang pendidikan diawali dari pendidikan usia dini hingga perguruan tinggi. Pada setiap jenjang pendidikan memiliki peran masing-masing dengan konteks isi yang berbeda namun dengan tujuan yang sama yaitu meningkatkan sumber daya manusia.

Dalam pendidikan, perserta didik mengukur kemampuan dari hasil belajarnya yang berupa nilai ataupun reward dalam bentuk lain. Hasil belajar berupa nilai yang baik dan reward dalam bentuk lain tersebut merupakan hal yang perlu dicapai dimana pencapaian itu sering disebut dengan prestasi. Seorang yang prestasinya tinggi dapat dikatakan bahwa ia telah berhasil dalam belajar. Prestasi belajar adalah sejauh mana tingkat pengetahuan anak terhadap materi yang diterima (Slameto, 1993:17)

Seluruh perguruan tinggi di Indonesia tentu mengaharapkan mahasiswanya berprestasi secara akademik di kampus serta dapat memproyeksikan prestasinya tersebut dalam persaingan hingga mencapai kesukesan di dunia kerja. Di Politeknik LP3I Jakarta kampus Blok
M, prestasi mahasiswa secara akademik masih belum dapat konsisten. Salah satu jurusan di Politeknik LP3I Jakarta Kampus Blok M dimana prestasi mahasiswanya masih belum konsisten yaitu jurusan Komputerisasi Akuntansi padahal untuk hasil yang sesuai ekspektasi seharusnya mahasiswa mempu menguasai materi yang digambarkan dari prestasi mereka yang konsisten.

Salah satu faktor dari dalam diri mahasiswa yang menentukan berhasil tidaknya mahasiswa dalam proses belajar mengajar adalah motivasi belajar. Motivasi belajar mahasiswa relatif masih rendah, belum berkembang seperti apa yang diharapkan. Hal tersebut terlihat dari berbagai aspek, diantaranya adalah tingkat kehadiran kuliah yang masih kurang, semangat belajar yang masih rendah, pengerjaan tugas kuliah yang masih serampangan serta IPK yang masih rendah.

Sedangkan faktor dari luar diri mahasiswa yang dapat mempengaruhi belajar adalah faktor metode pembelajaran. Selain mahasiswa, unsur terpenting yang ada dalam kegiatan pembelajaran adalah Dosen. Dosen sebagai pengajar yang memberikan ilmu pengetahuan sekaligus pendidik yang mengajarkan nilai-nilai, akhlak, moral maupun sosial dan untuk menjalankan peran tersebut seorang Dosen dituntut untuk memiliki pengetahuan dan wawasan yang luas yang nantinya akan diajarkan kepada mahasiswa. Namun dalam pelaksanaannya metode pembelajaran yang disampaikan dosen kepada para mahasiswanya dinilai masih terkendala, diantaranya tidak ada keseragaman metode pembelajaran antara satu dosen dengan lainnya, metode pembelajaran yang diberikan dosen dinilai sebagian masih menggunakan metode klasik (mengikuti cara lama) yang dilakukan secara searah dan belum interaktif, masih manual tanpa bantuan alat bantu seperti infokus (power point), kaku, materi kuliah didiktekan oleh dosen yang bersangkutan dll.

Dari fenomena di atas dapat diindikasikan 
Asmawi Mangku Alam, Pengaruh Motivasi Belajar Dan Metode Pembelajaran........

bahwa prestasi mahasiswa jurusan Komputerisasi Akuntansi belum konsisten atau optimal yang disebabkan oleh faktor motivasi belajar dan metode belajar yang diterapkan di kampus.Atas dasar pemikiran di atas, penulis tertarik untuk mengadakan penelitian dengan judul:"Pengaruh Motivasi Belajar dan Metode Pembelajaran terhadap Prestasi Belajar Mahasiswa Program Studi Komputerisasi Akuntasi Politeknik LP3I Jakarta Kampus Blok M"

\section{Motivasi Belajar}

Menurut Mulyasa (2003:112) motivasi adalah tenaga pendorong atau penarik yang menyebabkan adanya tingkah laku ke arah suatu tujuan tertentu. Peserta didik akan bersungguhsungguh karena memiliki motivasi yang tinggi. Seorang mahasiswa akan belajar bila ada faktor pendorongnya yang disebut motivasi.Dimyati dan Mudjiono (2002:80) mengutip pendapat Koeswara mengatakan bahwa mahasiswa belajar karena didorong kekuatan mental, kekuatan mental itu berupa keinginan dan perhatian, kemauan, cita-cita di dalam diri seorang terkadang adanya keinginan yang mengaktifkan, menggerakkan, menyalurkan dan mengarahkan sikap dan perilaku individu dalam belajar.

Menurut Max Darsono, dkk (2000:65) ada beberapa faktor yang mempengaruhi motivasi belajar adalah cita-cita atau aspirasi mahasiswa, kemampuan belajar, kondisi mahasiswa, kondisi lingkungan, unsur-unsur dinamis dalam belajar, upaya dosen dalam pembelajaran mahasiswa. Motivasi tersebut mempunyai peranan penting dalam proses belajar mengajar baik bagi dosen maupun mahasiswa. Bagi dosen mengetahui motivasi belajar dari mahasiswa sangat diperlukan guna memelihara dan meningkatkan semangat belajar mahasiswa. Bagi mahasiswa motivasi belajar dapat menumbuhkan semangat belajar sehingga mahasiswa terdorong untuk melakukan kegiatan belajar.

\section{Pengertian metode pembelajaran}

Menurut Sudjana (2005:76), metode pembelajaran adalah cara atau pendekatan yang dipergunakan dalam menyajikan atau menyampaikan materi pelajaran akuntansi. menempati peranan yang tak kalah penting dalam proses belajar mengajar. Dalam pemilihan metode apa yang tepat, dosen harus melihat situasi dan kondisi mahasiswa serta materi yang diajarkan.

Dalam kegiatan belajar mengajar daya serap peserta didik tidaklah sama. Dalam menghadapi perbedaan tersebut, strategi pengajaran yang tepat sangat dibutuhkan. Strategi belajar mengajar adalah pola umum perbuatan dosen dan mahasiswa dalam kegiatan mewujudkan kegiatan belajar mengajar (Hasibuan, 2004:3). Metode pembelajaran merupakan salah satu strategi pembelajaran yang dapat dilakukan oleh dosen untuk menghadapi masalah tersebut sehingga pencapaian tujuan pengajaran dapat tercapai dengan baik. Dengan pemanfaatan metode yang efektif dan efisien, dosen akan mampu mencapai tujuan pengajaran.

Dengan demikian dapat disimpulkan bahwa metode pembelajaran adalah strategi pembelajaran yang digunakan oleh dosen sebagai alat untuk mencapai tujuan pembelajaran.

Menurut Winarno Surakhmad dalam Djamarah (2002:89) pemilihan dan penentuan metode dipengaruhi oleh beberapa faktor, sebagai beriku anak didik, tujuan, situasi, fasilitas, dosen

\section{Pengertian Prestasi Belajar}

Prestasi merupakan hasil yang dicapai seseorang ketika mengerjakan tugas atau kegiatan tertentu (Tu'u 2004:75). Prestasi akademik merupakan hasil yang diperoleh dari kegiatan pembelajaran di kampus yang bersifat kognitif dan biasanya ditentukan melalui pengukuran dan penilaian. Prestasi belajar merupakan penguasaan terhadap mata pelajaran yang ditentukan lewat nilai atau angka yang diberikan guru. Berdasarkan hal ini, prestasi belajar dapat dirumuskan: 1). Prestasi belajar adalah hasil belajar yang dicapai ketika mengikuti, mengerjakan tugas dan kegiatan pembelajaran di kampus; 2). Prestasi belajar tersebut terutama dinilai aspek kognitifnya karena bersangkutan dengan kemampuan mahasiswa dalam pengetahuan atau ingatan, pemahaman, aplikasi, analisis, sintesa dan evaluasi; dan 3). Prestasi belajar 
dibuktikan dan ditunjukkan melalui nilai atau angka dari hasil evaluasi yang dilakukan oleh guru.

Jadi prestasi belajar berfokus pada nilai atau angka yang dicapai dalam proses pembelajaran di kampus. Nilai tersebut dinilai dari segi kognitif karena dosen sering memakainya untuk melihat penguasaan pengetahuan sebagai pencapaian hasil belajar mahasiswa.

Di sisi lain aspek atau indikator prestasi pelajar menurut Benjamin S. Bloom, sebagaimana yang dikutip oleh Abu Muhammad Ibnu Abdullah (2008), adalah sebagai berikut : a). Ranah kognitif(cognitive domain); $b$ ). Ranah afektif (affective domain); dan $c$ ). Ranah psikomotor (psychomotor domain

\section{Kerangka Konseptual}

Dari penjelasan diatas, maka dapat ilustrasikan dalam bentuk gambar kerangka konseptual sebagai berikut :

Motivasi Belajar

Dimensi :

1. Minat untuk belajar

2. Mengerjakan tugas

3. Memecahkan soal-soal

4. Kesulitan belajar

Metode Pembelajaran (X2)

Dimensi :

1. Membangkitkan motif dan minat belajar mahasiswa

2. Mendidik mahasiswa belajar sendiri membangkitkan keinginan belajar lebih lanju

3. Meminimalkan verbalitas dalam penyampaian materi

\section{Gambar Kerangka Pemikiran Teoritis}

\section{Hipotesis}

Hipotesis dalam penalitian ini adalah : 1). Motivasi belajar berpengaruh positif terhadap prestasi belajar mahasiswa Politeknik LP3I Jakarta Kampus Blok M; 2). Metode pembelajaran berpengaruh positif terhadap prestasi belajar mahasiswa Politeknik LP3I Jakarta Kampus Blok M; dan 3). Motivasi belajar dan metode pembelajaran secara bersama berpengaruh positif terhadap prestasi belajar mahasiswa Politeknik LP3I Jakarta Kampus Blok M.

\section{Metode penelitian}

\section{Pendekatan Penelitian}

Prestasi Belajar (Y)

Dimensi :

1. Kognitif

2. Afektif

3. Psikomotor penelitiandekatan yang digunakan dalam (2005) "survei adalah penelitian yang dilakukan untuk memperoleh fakta-fakta dan gejala-gejala yang ada serta mencari keterangan-keterangan secara faktual, baik tentang institusi sosial, ekonomi, atau politik dari suatu kelompok ataupun suatu daerah"

Jenis penelitian ini adalah deskriptif kuantitatif. Menurut Bungin (2005) penelitian deskriptif kuantitatif adalah penelitian yang menggambarkan, menjelaskan, atau meringkaskan berbagai kondisi, situasi, fenomena menurut kejadian sebagaimana adanya. 
Asmawi Mangku Alam, Pengaruh Motivasi Belajar Dan Metode Pembelajaran........

Adapun sifat penelitian ini adalah penelitian penjelasan (explanatory), yaitu suatu penelitian yang menguraikan dan menjelaskan fenomena yang terjadi di objek penelitian.

\section{Operasionalisasi Variabel}

Operasionalisasi variable dari penelitian yang diangkat penulis terdiri dari Variabel Motivasi belajar (X1) dan variabel Metode Pembelajaran (X2) sebagai variabel yang memengaruhi atau disebut juga sebagai variabel penyebab, atau sering disebut spebagai variabel bebas atau independent variable (X), serta variabel prestasi belajar sebagai yang dipengaruhi atau dependent variable.

Dalam Operasionalisasi Variabel tersebut berisi Kisi-kisi Variabel Penelitian yang memuat deskripsi dimensi (subvariabel), setiap dimensi dirumuskan indikatornya untuk kemudian menjadi item angket (quisionery).

Tabel Kisi-kisi Variabel

\begin{tabular}{|c|c|c|c|c|}
\hline Variabel & Dimensi & Indikator & No. Item & $\begin{array}{l}\text { Jumlah } \\
\text { Item }\end{array}$ \\
\hline \multirow[t]{5}{*}{$\begin{array}{l}\text { Motivasi Belajar } \\
\text { (X1) }\end{array}$} & $\begin{array}{l}\text { Minat untuk belajar } \\
\text { akuntansi }\end{array}$ & Dorongan belajar dari dalam diri & 1 & 1 \\
\hline & $\begin{array}{l}\text { Tekun dalam menghadapi } \\
\text { tugas }\end{array}$ & $\begin{array}{l}\text { Memiliki manajemen waktu untuk } \\
\text { pengerjaan tugas }\end{array}$ & 2 & 1 \\
\hline & $\begin{array}{l}\text { Senang memecahkan soal- } \\
\text { soal } \\
\text { Maksimal } 10 \text { pernyataan }\end{array}$ & $\begin{array}{l}\text { Tidak menyerah saat jawanban soal } \\
\text { salah }\end{array}$ & 3 & 1 \\
\hline & $\begin{array}{l}\text { Ulet dalam mengatasi } \\
\text { kesulitan belajar }\end{array}$ & $\begin{array}{l}\text { 1. Tidak mudah menyerah saat } \\
\text { menemui kesulitan belajar }\end{array}$ & & \\
\hline & & $\begin{array}{l}\text { 2. Selalu bertanya dan mencari } \\
\text { referensi saat sulit memahami } \\
\text { materi }\end{array}$ & 4,5 & 2 \\
\hline \multirow{4}{*}{$\begin{array}{l}\text { Metode } \\
\text { Pembelajaran (X2) } \\
\text { Sumber ... } \\
\text { Maksimal } 10 \\
\text { pernyataan }\end{array}$} & $\begin{array}{l}\text { Membangkitkan motif dan } \\
\text { minat belajar mahasiswa }\end{array}$ & $\begin{array}{l}\text { Sistem belajar yang serius tapi } \\
\text { menyenangkan }\end{array}$ & 6 & 1 \\
\hline & $\begin{array}{l}\text { Mendidik mahasiswa belajar } \\
\text { sendiri }\end{array}$ & $\begin{array}{l}\text { 1. Belajar mandiri dengan diskusi } \\
\text { kelompok } \\
\text { 2. Memaksimalkan penggunaan } \\
\text { sistem belajar berbasis internet }\end{array}$ & 7,8 & 2 \\
\hline & $\begin{array}{l}\text { Membangkitkan keinginan } \\
\text { belajar lebih lanjut }\end{array}$ & $\begin{array}{l}\text { Menanamkan pemahaman } \\
\text { perkembangan pesat dalam dunia } \\
\text { akuntansi }\end{array}$ & 9 & 1 \\
\hline & $\begin{array}{l}\text { Menanamkan dan } \\
\text { mengembangkan nilai dan } \\
\text { sikap kebiasaan yang baik }\end{array}$ & Memunculkan motivasi internal & 10 & 1 \\
\hline \multirow{4}{*}{$\begin{array}{l}\text { Prestasi Belajar } \\
\text { Mahasiswa Jurusan } \\
\text { Komputerisasi } \\
\text { Akuntansi } \\
\text { Politeknik Lp3i } \\
\text { Jakarta Kampus } \\
\text { Blok M } \\
\text { (Y) }\end{array}$} & Kognitif & $\begin{array}{l}\text { Pemahaman secara teori dalam } \\
\text { akuntansi }\end{array}$ & 11 & 1 \\
\hline & Afektif & $\begin{array}{l}\text { 1. Dasar belajar dengan perasaan } \\
\text { puas }\end{array}$ & & \\
\hline & & $\begin{array}{l}\text { 2. Kebanggan tersendiri dalam } \\
\text { penyelesaian soal akuntansi }\end{array}$ & 12,13 & 2 \\
\hline & Psikomotor & $\begin{array}{l}\text { 1. Rajin dalam mempelajari dan } \\
\text { pengerjaan soal } \\
\text { 2. Penguasaan secara praktek dalam } \\
\text { akuntansi }\end{array}$ & 14,15 & 2 \\
\hline
\end{tabular}

Jenis Data dan Teknik Pengumpulan Data

Teknik Pengumpulan Data dilakukan dalam beberapa tahap sebagai berikut adalah data primer meliputi: Observasi (pengamatan langsung di lokasi penelitian) dan kuesioner

\section{Populasi, Sample, dan Teknik Penarikan Sample}

Populasi adalah keseluruhan unit atau individu dalam ruang lingkup yang ingin diteliti (Sugiarto, 2001: 2). Adapun populasi dalam 
penelitian ini adalah warga belajar yang berjumlah 242 orang

Sample adalah sebagian anggota dari populasi yang dipilih dengan menggunakan prosedur tertentu sehingga diharapkan dapat mewakili populasinya, sedangkan banyaknya anggota suatu sampel disebut ukuran sampel (Sugiarto, 2001: 2).

Teknik pengambilan sample dilakukan sampling jenuh yaitu dengan mengambil 50 populasi semuanya sebagai sampel

\section{Teknik Analisis Data}

Dalam penelitian ini data yang dikumpulkan meliputi data kuantitatif maupun data kualitatif. Data kualitatif

\section{Uji Keabsahan Data}

Setelah data terkumpul, selanjutnya akan dilakukan uji keabsahan data dengan Uji Validitas, dan Uji Reliabilitas. Selanjutnya dalam pengolahan data, perlu dilakukan uji persyaratan analisis mencakup: Uji Normalitas,
Uji Multikolinieritas, Uji Autokorelasi, dan Uji Heterokedastisitas, Analisis Regresi Linear Berganda, Uji statistik $t, \quad$ Uji statistik $F$, Korelasi Product Moment dan Koefisien Determinasi

\section{Hasil Penelitian}

\section{Karakteristik Responden Jurusan Responden}

Responden yang menjadi sample dalam penelitian ini yaitu mahasiswa jurusan KA di Politeknik LP3I Jakarta Kampus Blok M sebanyak 50 mahasiswa yang diambil melalui teknik pengambilan sample dilakukan sampling jenuh yaitu dengan mengambil semua populasi yang berjumlah sebanyak 50 orang.

\section{Pendidikan Terakhir Responden}

Responden dalam penelitian ini dikelompokan berdasarkan Pendidikan terakhir yaitu SMA, SMK dan MA. Untuk lebih jelasnya hal tersebut tampak pada tabel berikut :

Tabel Pendidikan Terakhir Responden

\begin{tabular}{lll}
\hline $\begin{array}{c}\text { Pendidikan } \\
\text { Terakhir }\end{array}$ & Jumlah & $\%$ \\
\hline SMA & 20 & $40 \%$ \\
SMK & 28 & $56 \%$ \\
MA & 2 & $4 \%$ \\
Total & 50 & $100 \%$ \\
\hline
\end{tabular}

Sumber : Hasil penelitian, 2014

Dari tabel di atas dapat diketahui bahwa responden dalam penelitian ini pendidikan terakhirnya berasal dari SMA, MA dan SMK. Responden yang berlatar belakang pendidikan SMA sebanyak 20 mahasiswa atau $40 \%$, dari SMK 28 mahasiswa atau $56 \%$ dan dari MA sebanyak 2 mahasiswa atau $4 \%$.

\section{Pekerjaan Responden}

Responden dalam penelitian ini dikelompokan berdasarkan pekerjaan. Untuk lebih jelasnya pekerjaan responden tampak pada tabel berikut :

Tabel Pekerjaan Responden

\begin{tabular}{lll}
\hline \multicolumn{1}{c}{ Pekerjaan } & Jumlah & $\%$ \\
\hline Mahasiswa & 41 & $82 \%$ \\
Swasta & 9 & $18 \%$ \\
\hline Total & 50 & $100 \%$ \\
\hline
\end{tabular}

Sumber : hasil penelitian, 2014

Dari tabel di atas dapat dilihat bahwa sebagian besar responden hanya sebagai mahasiswa yaitu sebanyak 41 mahasiswa atau
$82 \%$ dan karyawan swasta sebanyak 9 mahasiswa atau $18 \%$. 
Asmawi Mangku Alam, Pengaruh Motivasi Belajar Dan Metode Pembelajaran........

\section{Jenis Kelamin Responden}

Responden dalam penelitian ini dikelompokan berdasarkan jenis kelaminnya yaitu laki-laki dan perempuan. Untuk lebih jelasnya pekerjaan responden tampak pada tabel berikut :

Tabel Jenis Kelamin Responden

\begin{tabular}{llll}
\hline \multicolumn{1}{c}{ Jenis Kelamin } & & Jumlah & $\%$ \\
\hline Laki-laki & 17 & $34 \%$ \\
Perempuan & 33 & $66 \%$ \\
\hline Total & 50 & $100 \%$ \\
\hline
\end{tabular}

Sumber : hasil penelitian, 2014

Dari tabel di atas dapat dilihat bahwa responden dalam penelitian ini terdiri dari 17 laki-laki atau $34 \%$ dan 33 perempuan atau 66 $\%$.

\section{Usia Responden}

Responden dalam penelitian ini dikelompokan berdasarkan Usia yaitu kurang dari 17 tahun, 17-19 tahun, 20-22 tahun, 23-24 tahun, dan di atas 25 tahun. Berikut penjelasan Usia responden dalam bentuk tabel :

Tabel Usia responden

\begin{tabular}{lll}
\hline \multicolumn{1}{c}{ Usia } & \multicolumn{1}{c}{ Jumlah } & $\%$ \\
\hline Kurang dari 17 tahun & 0 & $0 \%$ \\
17-19 tahun & 26 & $52 \%$ \\
20-22 tahun & 20 & $40 \%$ \\
$23-24$ tahun & 4 & $8 \%$ \\
Lebih dari 25 tahun & 0 & $0 \%$ \\
\hline Total & 50 & $100 \%$ \\
\hline
\end{tabular}

Sumber : hasil penelitian, 2014

Dari tabel di atas dapat diketahui bahwa sebagian besar responden berumur 17-19 tahun dengan jumlah 26 atau $52 \%$. Responden yang berumur kurang dari 17 tahun tidak ada, responden yang berumur 20-22 tahun sebanyak 20 mahasiswa atau $40 \%$, responden yang berumur 23-24 tahun sebanyak 4 mahasiswa

atau $8 \%$, dan yang berumur lebih dari 25 tahun tidak ada.

\section{Analisis Deskriftif}

Hubungan Korelasi menurut Sugiyono adalah sebagai berikut :

Tabel Pedoman interpretasi koefisien korelasi :

\begin{tabular}{cc}
\hline Interval Koefisien & Tingkat hubungan \\
\hline $0,00-0,199$ & Sangat rendah \\
$0,20-0,399$ & Rendah \\
$0,40-0,599$ & Sedang \\
$0,60-0,799$ & Kuat \\
$0,80-1,000$ & Sangat Kuat \\
\hline
\end{tabular}

\section{Analisis Deskriftif, Histogram dan Frequency Motivasi Belajar Analisis Deskriftif Motivasi Belajar}

Analisis Deskriptif motivasi belajar dapat ditunjukkan sebagai berikut

Tabel Analisis Deskriftif Motivasi Belajar

\begin{tabular}{lr}
\hline & Tot_Motivasi \\
\hline Valid & 50 \\
Missing & 0 \\
Mean & 10,7800 \\
Std. Deviation & 2,91576 \\
Minimum & 5,00 \\
Maximum & 18,00 \\
\hline Sumber : Hasil Olahan Data, 2014
\end{tabular}


Dari data di atas terlihat bahwa rata-rata data motivasi Belajar sebesar 10,7800, dengan nilai maksimum sebesar 18,00 dan nilai minimum sebesar 5,00

Histogram Variabel Motivasi

\section{Gambar Histogram Variabel Motivasi}

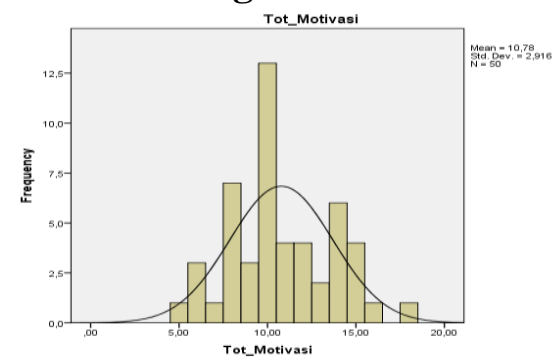

Dari gambar di tas terlihat data motivasi mahasiswa menyebar mendekati normal.

\section{Analisis Frequensi Variabel Motivasi} Table Frequensi Variabel Motivasi.

Tot_Motivasi

\begin{tabular}{lrrrr}
\hline & Frequency & Percent & Valid Percent & Cumulative Percent \\
\hline 5,00 & 1 & 2,0 & 2,0 & 2,0 \\
6,00 & 3 & 6,0 & 6,0 & 8,0 \\
7,00 & 1 & 2,0 & 2,0 & 10,0 \\
8,00 & 7 & 14,0 & 14,0 & 24,0 \\
9,00 & 3 & 6,0 & 6,0 & 30,0 \\
10,00 & 13 & 26,0 & 26,0 & 56,0 \\
11,00 & 4 & 8,0 & 8,0 & 64,0 \\
12,00 & 4 & 8,0 & 8,0 & 72,0 \\
13,00 & 2 & 4,0 & 4,0 & 76,0 \\
14,00 & 6 & 12,0 & 12,0 & 88,0 \\
15,00 & 4 & 8,0 & 8,0 & 96,0 \\
16,00 & 1 & 2,0 & 2,0 & 98,0 \\
18,00 & 1 & 2,0 & 2,0 & 100,0 \\
\hline Total & 50 & 100,0 & 100,0 & \\
\hline Sumber & & & & \\
\hline
\end{tabular}

Sumber : Hasil Olahan data, 2014

Analisis Deskriftif, histogram dan Frequency Metode Belajar

Analisis Deskriptif Metode belajar dapat ditunjukkan sebagai berikut

Tabel Analisis Deskriptif Metode Belajar

\begin{tabular}{lr}
\hline & Tot_Metode \\
\hline Valid & 50 \\
Missing & 0 \\
Mean & 8,2000 \\
Std. Deviation & 2,32993 \\
Minimum & 5,00 \\
Maximum & 14,00 \\
\hline
\end{tabular}

Sumber : Hasil Olahan Data, 2014

Dari data di atas terlihat bahwa rata-rata data Metode Belajar sebesar 8,2000, dengan nilai maksimum sebesar 14,00 dan nilai minimum sebesar 5,00

Histogram variable Metode Belajar 
Asmawi Mangku Alam , Pengaruh Motivasi Belajar Dan Metode Pembelajaran.........

Gambar Histogram Variabel Metode Belajar

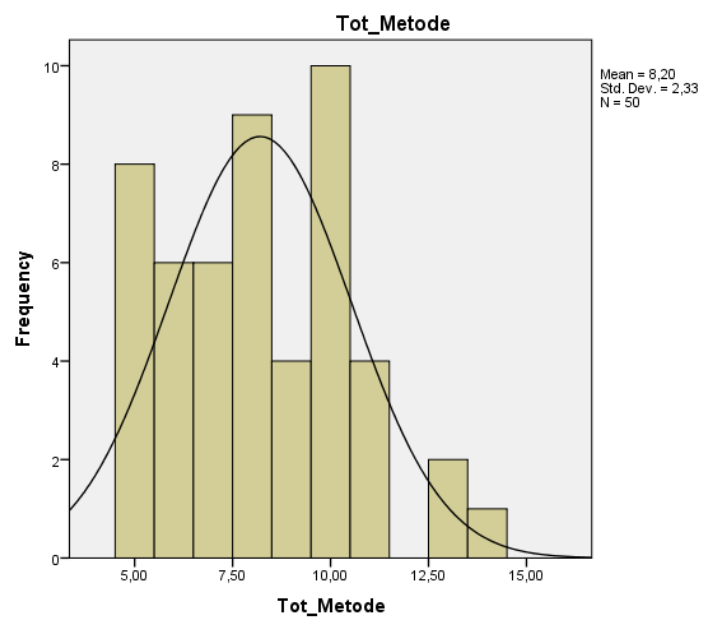

Dari gambar di tas terlihat data metode Table Frequensi Metode Belajar . belajar mahasiswa menyebar mendekati normal.

Tot_Metode

\begin{tabular}{lrrrr}
\hline & & \multicolumn{2}{c}{ Valid } & \multicolumn{2}{c}{ Cumulative } \\
& Frequency & Percent & \multicolumn{1}{c}{ Percent } & Percent \\
\hline 5,00 & 8 & 16,0 & 16,0 & 16,0 \\
6,00 & 6 & 12,0 & 12,0 & 28,0 \\
17,00 & 6 & 12,0 & 12,0 & 40,0 \\
$\mathrm{i} 8,00$ & 9 & 18,0 & 18,0 & 58,0 \\
19,00 & 4 & 8,0 & 8,0 & 66,0 \\
10,00 & 10 & 20,0 & 20,0 & 86,0 \\
11,00 & 4 & 8,0 & 8,0 & 94,0 \\
13,00 & 2 & 4,0 & 4,0 & 98,0 \\
14,00 & 1 & 2,0 & 2,0 & 100,0 \\
\hline Total & 50 & 100,0 & 100,0 & \\
\hline Sumbro
\end{tabular}

Sumber : Data Olahan 2014

\section{Analisis Deskriftif, Histogram dan \\ Frequensi Prestasi Belajar}

Tabel Analisis Deskriftif Prestasi Belajar

\begin{tabular}{lr}
\hline & Tot_Prestasi \\
\hline Valid & 50 \\
Missing & 0 \\
Mean & 11,5000 \\
Std. Deviation & 2,83023 \\
Minimum & 6,00 \\
Maximum & 17,00 \\
\hline
\end{tabular}

Sumber : Data Olahan 2014

Dari data di atas terlihat bahwa rata-rata nilai maksimum sebesar 17,00 dan nilai data Prestasi Belajar sebesar 11,5000, dengan minimum sebesar 6,00

Histogram variable Prestasi

Gambar Histogram Variabel Prestasi 
Majalah Ilmiah Ilmu Administrasi

ISSN 1411-0830

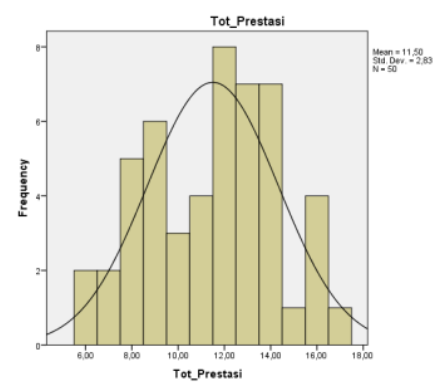

Dari gambar di atas terlihat bahwa data Prestasi mendekati normal

Table 10. Frequensi Prestasi.

Tot_Prestasi

\begin{tabular}{lrrrr}
\hline & & \multicolumn{2}{c}{ Valid } & Cumulative \\
& Frequency & Percent & Percent & Percent \\
\hline 6,00 & 2 & 4,0 & 4,0 & 4,0 \\
$: 7,00$ & 2 & 4,0 & 4,0 & 8,0 \\
18,00 & 5 & 10,0 & 10,0 & 18,0 \\
$j 9,00$ & 6 & 12,0 & 12,0 & 30,0 \\
110,00 & 3 & 6,0 & 6,0 & 36,0 \\
11,00 & 4 & 8,0 & 8,0 & 44,0 \\
12,00 & 8 & 16,0 & 16,0 & 60,0 \\
13,00 & 7 & 14,0 & 14,0 & 74,0 \\
14,00 & 7 & 14,0 & 14,0 & 88,0 \\
15,00 & 1 & 2,0 & 2,0 & 90,0 \\
16,00 & 4 & 8,0 & 8,0 & 98,0 \\
17,00 & 1 & 2,0 & 2,0 & 100,0 \\
Total & 50 & 100,0 & 100,0 & \\
\hline
\end{tabular}

Sumber : Data Olahan 2014

Dari data di atas terlihat bahwa frekuensi data menyebar, dengan data tertinggi sebesar 49

D. Uji Validitas dan Reliabilitas Data (3\%), data terendah sebesar $20(1 \%)$ dan datæ. Uji Validitas dan Reliabilitas Variabel Motivasi terbanyak 40 masing-masing sebesar $18 \%$.

Tabel Uji Validitas Variabel MotivasiItem-Total Statistics

\begin{tabular}{lrrrrr} 
& \multicolumn{2}{c}{ Item-Total Statistics } \\
& $\begin{array}{c}\text { Scale } \\
\text { Scale Mean if } \\
\text { Item Deleted }\end{array}$ & $\begin{array}{c}\text { Corrected } \\
\text { Item Deleted } \\
\text { Item-Total } \\
\text { Correlation }\end{array}$ & $\begin{array}{c}\text { Squared } \\
\text { Multiple } \\
\text { Correlation }\end{array}$ & $\begin{array}{c}\text { Cronbach's } \\
\text { Alpha if Item } \\
\text { Deleted }\end{array}$ \\
\hline Motivasi_1 & 8,9200 & 6,198 &, 520 &, 304 &, 722 \\
Motivasi_2 & 8,4600 & 6,213 &, 419 &, 358 &, 753 \\
Motivasi_3 & 8,4800 & 4,622 &, 591 &, 452 &, 704 \\
Motivasi_4 & 8,2200 & 5,440 &, 666 &, 500 &, 668 \\
Motivasi_5 & 9,0400 & 6,366 &, 506 &, 321 &, 728 \\
\hline
\end{tabular}

Sumber data : Hasil Olahan 2014

Dari data di atas terlihat bahwa datb. Uji Reliabilitas bernila valid, hal tersebut terbukti dari nilai $r$ Tabel Uji Reliability Statistics of Motivasi hitung lebih besar dari nilai $r$ kritis yaitu sebesar 0.3 


\section{Reliability Statistics}

\begin{tabular}{rrrr}
\hline $\begin{array}{c}\text { Cronbach's } \\
\text { Alpha }\end{array}$ & $\begin{array}{c}\text { Cronbach's Alpha Based } \\
\text { on Standardized Items }\end{array}$ & N of Items \\
\hline, 760 &, 767 & 5 \\
\hline
\end{tabular}

Dari data diatas ternyata data bersifat. Uji Validitas \& Realibilitas Variabel Metode reliable, karena terlihat bahwa nilai koefisen Belajar alpha Cronbach yang sebesar 0.760 lebih besari. Uji Validitas dari 0,6 .

\section{Tabel Uji Validity Variabel Metode Belajar}

\begin{tabular}{lrrrrr}
\hline & \multicolumn{2}{c}{ Item-Total Statistics } & & \\
& $\begin{array}{c}\text { Scale Mean } \\
\text { if Item } \\
\text { Deleted }\end{array}$ & $\begin{array}{c}\text { Scale } \\
\text { Variance if } \\
\text { Item Deleted }\end{array}$ & $\begin{array}{c}\text { Corrected } \\
\text { Item-Total } \\
\text { Correlation }\end{array}$ & $\begin{array}{c}\text { Squared } \\
\text { Multiple } \\
\text { Correlation }\end{array}$ & $\begin{array}{c}\text { Cronbach's } \\
\text { Alpha if } \\
\text { Item Deleted }\end{array}$ \\
\hline Metode_6 & 6,6800 & 3,896 &, 370 &, 200 &, 696 \\
Metode_7 & 6,3200 & 3,447 &, 482 &, 259 &, 651 \\
Metode_8 & 6,8200 & 4,069 &, 453 &, 227 &, 665 \\
Metode_9 & 6,2800 & 3,349 &, 628 &, 398 &, 585 \\
Metode_10 & 6,7000 & 3,888 &, 405 &, 217 &, 681 \\
\hline
\end{tabular}

Sumber Data : hasil Olahan data, 2014

Dari data di atas terlihat bahwa semua data bernilai valid, hal tersebut terbukti dari nilai $\mathrm{r}$ hitung lebih besar dari nilai $\mathrm{r}$ kritis yaitu sebesar 0.3

Tabel Uji reliability Statistic of Method Reliability Statistics

\begin{tabular}{ccc}
\hline & $\begin{array}{c}\text { Cronbach's Alpha } \\
\text { Based on } \\
\text { Standardized } \\
\text { Items }\end{array}$ & N of Items \\
\hline Cronbach's Alpha &, 709 & 5 \\
\hline
\end{tabular}

Sumber Data : Hasil Olahan Data, 2014

Dari data diatas ternyata data bersifat alpha Cronbach yang sebesar 0.706 lebih besar reliable, karena terlihat bahwa nilai koefisen dari 0,6.

\begin{tabular}{|c|c|c|c|c|c|}
\hline \multicolumn{6}{|c|}{$\begin{array}{c}\text { Uji Validitas dan reliabilitas Prestasi } \\
\text { Tabel Uji Validitas Prestasi } \\
\text { Item-Total Statistics }\end{array}$} \\
\hline & $\begin{array}{l}\text { Scale Mean } \\
\text { if Item } \\
\text { Deleted }\end{array}$ & $\begin{array}{c}\text { Scale } \\
\text { Variance if } \\
\text { Item Deleted }\end{array}$ & $\begin{array}{l}\text { Corrected } \\
\text { Item-Total } \\
\text { Correlation }\end{array}$ & $\begin{array}{c}\text { Squared } \\
\text { Multiple } \\
\text { Correlation }\end{array}$ & $\begin{array}{l}\text { Cronbach's } \\
\text { Alpha if Item } \\
\text { Deleted }\end{array}$ \\
\hline Prestasi_11 & 9,0400 & 5,509 & ,538 & ,317 & ,763 \\
\hline Prestasi_12 & 9,4400 & 5,517 & ,500 & ,337 & ,776 \\
\hline Prestasi_13 & 9,2400 & 5,778 &, 561 & ,331 & ,758 \\
\hline Prestasi_14 & 9,1200 & 5,210 &, 557 &, 385 & ,758 \\
\hline Prestasi_15 & 9,1600 & 4,953 & ,716 &, 544 & ,704 \\
\hline
\end{tabular}

Dari data di atas terlihat bahwa semua data bernilai valis, hal tersebut terbukti dari nilai $\mathrm{r}$ hitung lebih besar dari nilai $\mathrm{r}$ kritis yaitu sebesar 0.3 
ISSN 1411-0830

Tabel Uji Reliabilitas Prestasi

Reliability Statistics

\begin{tabular}{|c|c|c|}
\hline $\begin{array}{l}\text { Cronbach's } \\
\text { Alpha }\end{array}$ & $\begin{array}{l}\text { Cronbach's Alpha Based on } \\
\text { Standardized Items }\end{array}$ & $\mathrm{N}$ of Items \\
\hline ,792 & ,794 & 5 \\
\hline
\end{tabular}

Sumber : Hasil Olahan Data, 2014

Dari data diatas ternyata data bersifat reliable, karena terlihat bahwa nilai koefisen

\section{Uji Normalitas Data}

Salah satau syarat yang harus dipenuhi dalam analisis regresi adalah data dan model regresi berdistribusi normal. Kenormalan data dapat dilihat dari uji normalitas KolmogorovSmirnof dari masing-masing variabel (Santoso 1999:311). alpha Cronbach yang sebesar 0.792 lebih besar dari 0,6.

\section{Uji Normalitas Variabel Motivasi}

Dengan menggunakan analisis non parametric, diperoleh Tabel normalitas untuk variable motivasi sebagai berikut :

\section{Tabel Uji Normalitas variable Motivasi}

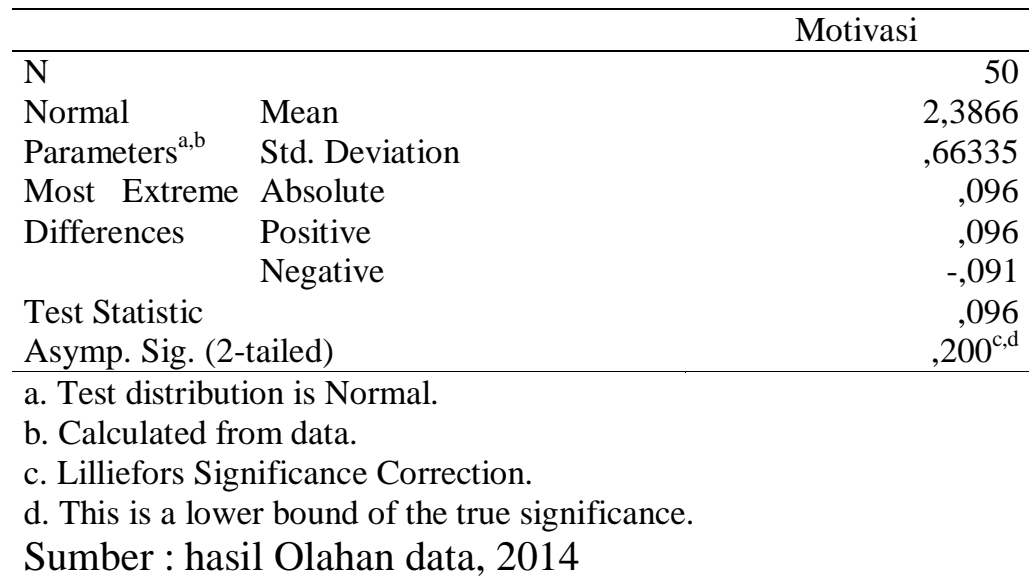

Dari analisis di atas terlihat bahwa asymp sig sebesar $0.200>0.05$, sehingga dapat disimpulkan variable bersifat normal

Table Uji Normalitas variable Metode Belajar

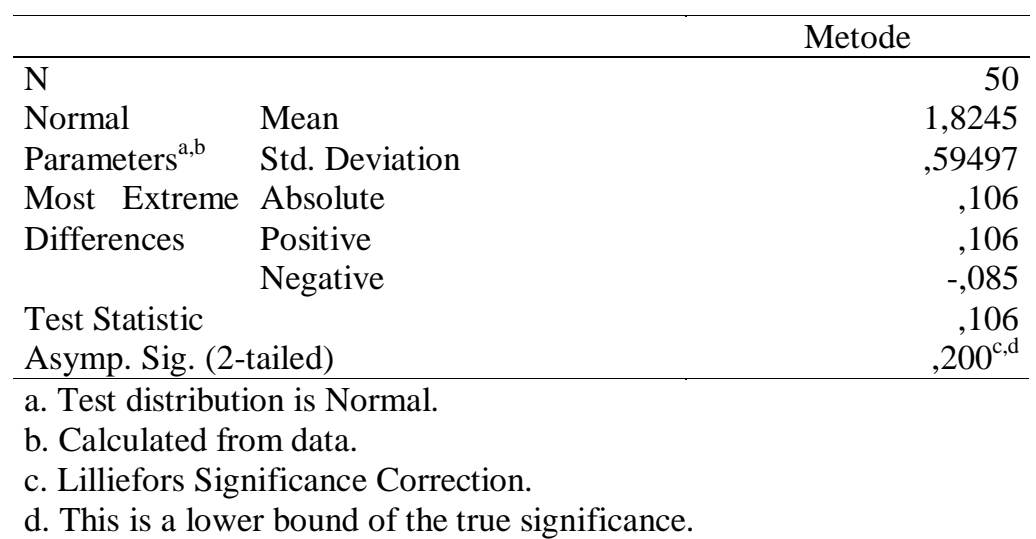

Sumber : hasil Olahan data, 2014 
Dari analisis di atas terlihat bahwa asymp sig sebesar $0.200>0.05$, sehingga dapat disimpulkan variable bersifat normal

Table Uji Normalitas variable Prestasi Belajar

\begin{tabular}{|c|c|c|}
\hline & & Prestasi \\
\hline \multicolumn{2}{|l|}{$\mathrm{N}$} & 50 \\
\hline \multirow{2}{*}{$\begin{array}{l}\text { Normal } \\
\text { Parameters }\end{array}$} & Mean & 2,6037 \\
\hline & Std. Deviation & 68571 \\
\hline \multirow{3}{*}{$\begin{array}{l}\text { Most Extreme } \\
\text { Differences }\end{array}$} & Absolute &, 121 \\
\hline & Positive & ,096 \\
\hline & Negative &,- 121 \\
\hline \multicolumn{2}{|l|}{ Test Statistic } & 121 \\
\hline \multicolumn{2}{|c|}{ Asymp. Sig. (2-tailed) } &, $065^{\mathrm{c}}$ \\
\hline
\end{tabular}
a. Test distribution is Normal.
b. Calculated from data.
c. Lilliefors Significance Correction.
$\mathrm{d}$. This is a lower bound of the true significance.

Sumber : hasil Olahan data, 2014

Dari analisis di atas terlihat bahwa asymp sig sebesar $0.065>0.05$, sehingga dapat disimpulkan variable bersifat normal

Data dianalisis dengan bantuan komputer program SPSS statistik 17. Dasar pengambilan keputusan berdasarkan probabilitas. Jika probabilitas $>0,05$ maka data penelitian berdistribusi normal.

\section{Uji Analisis Regresi}

Berdasarkan perhitungan analisis regresi linier yang dilakukan melalui analisa statistik dengan mengunakan program SPSS 17. Hasil analisis tersebut selengkapnya dapat dilihat pada tabel.

\begin{tabular}{|c|c|c|c|}
\hline Summary $^{b}$ & \multicolumn{2}{|c|}{ Pengaruh Motivasi terhadap Prestasi } & \multirow[b]{2}{*}{$\begin{array}{l}\text { Std. Error of the } \\
\text { Estimate }\end{array}$} \\
\hline Model & R Square & $\begin{array}{l}\text { Adjusted R } \\
\text { Square }\end{array}$ & \\
\hline 1 &, $682^{\mathrm{a}}$ & ,454 & ,50654 \\
\hline \multicolumn{4}{|c|}{ a. Predictors: (Constant), Motivasi } \\
\hline b. Depende & e: Prestasi & & \\
\hline Sumber : ha & data, 2014 & & \\
\hline
\end{tabular}

\begin{tabular}{|c|c|c|c|c|c|}
\hline \multicolumn{6}{|c|}{ ANOVA $^{a}$} \\
\hline & & & Mean & & \\
\hline Model & Sum of Squares & Df & Square & $\mathrm{F}$ & Sig. \\
\hline Regression & 10,724 & 1 & 10,724 & 41,794 &, $000^{\mathrm{b}}$ \\
\hline Residual & 12,316 & 48 & 257 & & \\
\hline Total & 23,039 & 49 & & & \\
\hline \multicolumn{6}{|c|}{$\begin{array}{l}\text { a. Dependent Variable: Prestasi } \\
\text { b. Predictors: (Constant), Motivasi } \\
\text { Sumber : hasil Olahan data, } 2014\end{array}$} \\
\hline \multicolumn{6}{|l|}{ Coefficient } \\
\hline & Unstandardized & Coefficients & $\begin{array}{l}\text { Standardized } \\
\text { Coefficients }\end{array}$ & & \\
\hline Model & $\mathrm{B}$ & Std. Error & Beta & $\mathrm{t}$ & Sig. \\
\hline (Constant) & ,921 & 270 & & 3,410 & ,001 \\
\hline Motivasi & ,705 & , 109 & ,682 & 6,465 &, 000 \\
\hline
\end{tabular}


Majalah Ilmiah Ilmu Administrasi

ISSN 1411-0830

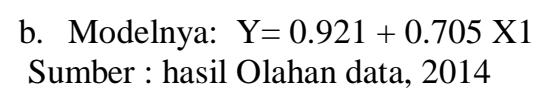

Pengaruh Metode terhadap Prestasi

\begin{tabular}{|c|c|c|c|c|}
\hline \multicolumn{5}{|c|}{ Model Summary } \\
\hline Model & $\mathrm{R}$ & R Square & $\begin{array}{l}\text { Adjusted R } \\
\text { Square }\end{array}$ & $\begin{array}{l}\text { Std. Error of the } \\
\text { Estimate }\end{array}$ \\
\hline 1 & $458^{\mathrm{a}}$ & 210 & ,193 & ,61586 \\
\hline \multicolumn{5}{|c|}{ a. Predictors: (Constant), Metode } \\
\hline \multicolumn{5}{|c|}{ b. Dependent Variable: Prestasi } \\
\hline \multicolumn{5}{|c|}{ Sumber : hasil Olahan data, 2014} \\
\hline
\end{tabular}

\begin{tabular}{|c|c|c|c|c|c|}
\hline \multicolumn{6}{|c|}{ ANOVA $^{b}$} \\
\hline Model & $\begin{array}{l}\text { Sum of } \\
\text { Squares }\end{array}$ & Df & $\begin{array}{c}\text { Mean } \\
\text { Square }\end{array}$ & $\mathrm{F}$ & Sig. \\
\hline 1Regression & 4,834 & 1 & 4,834 & 12,744 &, $001^{\mathrm{b}}$ \\
\hline Residual & 18,206 & 48 & ,379 & & \\
\hline Total & 23,039 & 49 & & & \\
\hline \multicolumn{6}{|c|}{ a. Dependent Variable: Prestasi } \\
\hline $\begin{array}{l}\text { b. Predictor } \\
\text { Sumber : ha }\end{array}$ & & & & & \\
\hline
\end{tabular}

\begin{tabular}{lcrrrr}
\hline \multicolumn{7}{c}{ Unstandardized Coefficients } & \multicolumn{2}{c}{$\begin{array}{c}\text { Standardized } \\
\text { Coefficients }\end{array}$} \\
Model & B & Std. Error & Beta & T & Sig. \\
\hline (Constant) & 1,641 &, 284 & & 5,787 &, 000 \\
Metode &, 528 &, 148 &, 458 & 3,570 &, $001^{*}$ \\
\hline Dependent Variable: Prestasi & & & &
\end{tabular}

Sumber : hasil Olahan data, 2014

Modelnya: $Y=1,641+0,528$ X2

Berdasarkan table summary di atas, nilai koefisien korelasi R sebesar 0.458 atau korelasi antara metode dan Prestasi kuat (Sugiyono, 2003)

Koefisien determinasi ( $\mathrm{R}$ square) sebesar 0.2097, artinya variable Metode mempengaruhi prestasi sebesar 20,97\% Berdasarkan Tabel ANOVA, diperoleh nilai $\mathrm{F}$ sebesar 12,744, jadi telah dipenuhi uji $\mathrm{F}$
Berdasarkan model regresi tersebut diperoleh koefisien regresi variable metode sebesar 0,528 yang berarti bahwa setiap terjadi peningkatan metode belajar mahasiswa sebesar satu satuan maka akan menyebabkan peningkatan atau kenaikan prestasi belajar sebesar 0.528. Secara umum menunjukkan bahwa perubahan metode dan disiplin ke arah positif akan diikuti dengan peningkatan prestasi belajar mahasiswa.

\section{Pengaruh Motivasi dan Metode terhadap Prestasi belajar}

Model Summary

\begin{tabular}{lrrrr} 
Model & R & R Square & Adjusted R Square & Std. Error of the Estimate \\
\hline 1 &, $687^{\mathrm{a}}$ &, 472 &, 450 &, 50854 \\
\hline
\end{tabular}

a. Predictors: (Constant), Motivasi, Metode

b. Dependent Variable: Prestasi

Sumber : hasil Olahan data, 2014 
Berdasarkan nilai summary di atas nilai $\mathrm{R}$ sebesar 0.687 yang artinya korelasi antara motivasi dan disiplin mahasiswa dengan prestasi sebesar 0.687 atau kuat
Kofisien Determinasi ( $\mathrm{R}$ square) sebesar 0.4719 artinya variable motivasi dan disiplin mempengaruhi prestasi sebesar 0.4719 atau $47,19 \%$.

\begin{tabular}{|c|c|c|c|c|c|}
\hline \multirow[b]{2}{*}{ Model } & \multicolumn{5}{|c|}{ Standardized } \\
\hline & B & Std. Error & Beta & $\mathrm{t}$ & Sig. \\
\hline 1 (Constant) & 850 & 286 & & 2,977 & ,005 \\
\hline Motivasi & ,645 & ,133 & 624 & 4,837 & , 000 \\
\hline Metode & ,117 & ,149 & ,102 & ,789 & 434 \\
\hline
\end{tabular}

Berdasarkan hasil analisis diperoleh model regresi hubungan antara motivasi (X1) dan disiplini $(\mathrm{X} 2)$, dengan prestasi belajar $(\mathrm{Y}): \mathrm{Y}=$ $0,850+0.645 \mathrm{X} 1+0.117 \mathrm{X} 2$

Berdasarkan model regresi tersebut diperoleh koefisien regresi variable motivasi sebesar 0.645 , Variable metode sebesar 0.117 yang berarti bahwa setiap terjadi peningkatan motivasi belajar mahasiswa sebesar satu satuan maka akan menyebabkan peningkatan atau kenaikan prestasi belajar sebesar 0.645 dan setiap terjadi peningkatan metode mahasiswa sebesar satu satuan maka akan menyebabkan peningkatan atau kenaikan prestasi belajar sebesar 0.117. Secara umum menunjukkan bahwa perubahan motivasi dan disiplin ke arah positif akan diikuti dengan peningkatan prestasi belajar mahasiswa.

Tabel ANOVA

\begin{tabular}{llrrrrr}
\hline Model & & Sum of Squares & Df & Mean Square & F & Sig. \\
\hline 1 & Regression & 10,885 & 2 & 5,442 & 21,045 &, $000^{\mathrm{b}}$ \\
& Residual & 12,155 & 47 &, 259 & & \\
& Total & 23,039 & 49 & & & \\
\hline
\end{tabular}

a. Dependent Variable: Prestasi

b. Predictors: (Constant), Metode, Motivasi

Sumber : hasil Olahan data, 2014

Dari table ANOVA di atas diperoleh nilai F sebesar 21,045 sehingga terpenuhi uji

Pembuktian Hipotesi

\section{Pembuktian Pengaruh Motivasi dengan Prestasi}

$\mathrm{HO}=0 \quad$ : Tidak terdapat hubungan antara Motivasi dengan Prestasi Mahasiswa.

$\mathrm{H} 1>0$ : Terdapat hubungan antara Motivasi dengan Prestasi Mahasiswa.

Dari hasil perhitungan diperoleh nilai t hitung untuk variabel motivasi adalah sebesar 4.837 dan dengan menggunakan level significance (taraf signifikasi) sebesar 5\% diperoleh t tabel sebesar 2,011 yang berarti bahwa nilai t hitung lebih dari t tabel yaitu $4.837>2,011$. Nilai signifikasi t lebih kurang dari $5 \%(0,000)$, menandakan bahwa Motivasi (X1) mempunyai pengaruh yang positif dan berpengaruh secara signifikan terhadap prestasi (Y) pada taraf nyata $5 \%$. Dengan demikian dapat disimpulkan bahwa Ho ditolak dan $\mathrm{H} 1$ diterima, sehingga hipotesis yang menyatakan motivasi mempunyai pengaruh terhadap prestasi dapat diterima.

\section{Pembuktian Pengaruh Metode dengan Prestasi \\ $\mathrm{H} 0=0$ : Tidak terdapat hubungan antara Disiplin dengan Prestasi Mahasiswa. \\ H1 >0 : Terdapat hubungan antara Displini dengan Prestasi Prestasi Mahasiswa}


Dari hasil perhitungan diperoleh nilai t hitung untuk variabel Metode adalah sebesar 0.789 dan dengan menggunakan level significance (taraf signifikasi) sebesar 5\% diperoleh $t$ tabel sebesar 2,011 yang berarti bahwa nilai t hitung lebih besar dari $\mathrm{t}$ tabel yaitu $0.789<2,011$. Nilai signifikasi $\mathrm{t}$ lebih dari $5 \% \quad(0,434)$, menandakan bahwa Metode (X2) mempunyai pengaruh yang positif namun tidak berpengaruh signifikan terhadap prestasi (Y). Dengan demikian dapat disimpulkan bahwa Ho diterima, sehingga hipotesis yang menyatakan bahwa variabel metode tidak mempunyai pengaruh terhadap prestasi dapat diterima

\section{Pembuktian Pengaruh Motivasi dan Metode terhadap Prestasi}

$\mathrm{HO}=0$ : Tidak terdapat hubungan antara Motivasi dan Disiplin dengan Prestasi Mahasiswa.

$\mathrm{H} 1>0$ : Terdapat hubungan antara Motivasi dan Displin dengan Prestasi Prestasi Mahasiswa

Berdasarkan tabel di atas menunjukkan hasil perhitungan uji $\mathrm{F}$ diperoleh nilai F-hitung sebesar 21.045 dengan tingkat signifikansi sebesar 0,000 $(<0,05)$.

Sementara nilai F-tabel sebesar 2,70 (dari perhitungan $\mathrm{db} 1=2$, alpha $=0,05$ dan $\mathrm{db}=50-2$ $1=47$ diperoleh $\mathrm{F}$ table sebesar 3,195). Ini berarti bahwa F-hitung (21.045) > F tabel $(3,195)$ dengan demikian Ho ditolak dan H1 diterima, artinya bahwa motivasi dan metode berpengaruh secara simultan atau bersama-sama terhadap prestasi.

\section{Pembahasan}

\section{Pembahasan Hasil Penelitian}

Dengan melibatkan sebanyak 50 orang responden, memberikan informasi mengenai pengaruh dari variabel motivasi belajar dan metode belajar terhadap prestasi mahasiswa.

Dari tabel tersebut dapat diterangkan bahwa angka $\mathrm{R}$ square sebesar 0, 4719 yang artinya bahwa variasi dari semua variabel bebas yaitu motivasi belajar dan metode belajar dapat menerangkan variabel prestasi mahasiswa sebesar 47,19 \%, sedangkan sisanya sebesar
$52,81 \%$ diterangkan oleh variabel lain yang tidak diajukan dalam penelitian ini.

Dari tabel uji validitas dapat diketahui bahwa variabel motivasi belajar, metode belajar serta prestasi mahasiswa mempunyai $r$ hitung yang lebih besar daripada $r$ kritis 0,3 , sehingga dapat dikatakan bahwa semua indikator pertanyaan yang digunakan dalam penelitian ini adalah valid.

Dari tabel uji reliabilitas dapat diketahui bahwa masing-masing variabel yaitu motivasi belajar, metode belajar serta prestasi mahasiswa diperoleh nilai Cronbach Alpha $\geq 0,60$. Dengan demikian, maka hasil uji reabilitas terhadap keseluruhan variabel adalah reliabel.

Dari data juga menunjukkan bahwa maka model regresi memenuhi asumsi normalitas.

Dari uji $\mathrm{t}$ diketahui bahwa nilai $\mathrm{t}$ hitung $>\mathrm{t}$ tabel dan tingkat signifikan $<0,05$ Sehingga dapat disimpulkan bahwa variabel baik motivasi maupun metode belajar secara parsial berpengaruh terhadap prestasi mahasiswa.

Dari uji $F$ juga di ketahui bahwa $F$ hitung $>\mathrm{F}$ tabel dan tingkat signifikasi $<0,05$ sehingga dapat disimpulkan bahwa variabel motivasi belajar dan metode belajar secara bersama-sama berpengaruh terhadap prestasi mahasiswa.

\section{Pembahasan Implementasi Hasil Penelitian}

Dengan melihat hasil penelitian di atas, terlihat bahwa korelasi (kaitan) antara motivasi belajar dan metode belajar dengan prestasi mahasiswa terlihat memiliki pengaruh yang kuat. Hal tersebut ditunjukkan dengan nilai koefisien korelasi sebesar 0.687. Adapun kontribusi motivasi belajar dan metode belajar terhadap prestasi mahasiswa memiliki prosentase yang cukup besar. Hal tersebut ditunjukkan oleh koefisien determinasi sebesar 47,197\%.

Dari data di atas jelaslah sudah bahwa peranan motivasi belajar dan metode belajar sangat strategis dan menentukan dalam mempengaruhi prestasi mahasiswa, karena prestasi suatu lembaga pendidikan salah satu diantaranya diukur dengan prestasi mahasiswa. 
Asmawi Mangku Alam, Pengaruh Motivasi Belajar Dan Metode Pembelajaran........

Semakin tinggi prestasi mahasiswa, semakin tinggi prestasi lembaga pendidikan tersebut.

Kita menyadari bahwa prestasi mahasiswa merupakan faktor yang menentukan eksisitensi lembaga pendidikan, karena kita mengetahui bahwa kehadiran persaingan pendidikan di antara perguruan tinggi berjalan sangat ketat, sehinga disadari atau tidak, langsung maupun tidak langsung, prestasi mahasiswa merupakan faktor yang sangat mempengaruhi prestasi lembaga, sehingga prestasi lembaga tersebut menentukan pula calon mahasiswa dalam memilih perguruan tinggi mana yang akan mereka pilih.

Dengan demikian prestasi mahasiswa tersebut haruslah disikapi dengan bijak oleh pihak pimpinan setiap perguruan tinggi, jika lembaga tersebut ingin tetap eksis, maju dan berkembang.

Kita mengetahui bahwa setiap Perguruan Tinggi senantiasa berusaha semaksimal mungkin untuk menjaring perolehan jumlah mahasiswa sebanyakbanyaknya. Berbagai upaya dilakukan melalui promosi untuk menjaring minat konsumen, salah satu diantaranya adalah dengan memenuhi harapan mereka dengan menghasilkan lulusan yang berprestasi

Untuk menciptakan prestasi tersebut jelas harus memperhatikan, menciptakan dan menumbuhkan motivasi dan metode belajar yang tepat untuk mereka dengan berbagai cara, karena jika tidak maka lembaga pendidikan tersebut akan tidak atau kurang berkualitas, tidak diminati, kalah bersaing dan akhirnya hancur (tutup).

Sehingga dengan demikian kunci pengembangan lembaga terletak pada prestasi mahasiswa/lulusannya, yang berarti bahwa jika lembaga pendidikan ingin senantiasa eksis, maju dan berkembang, maka ia harus menghasilkan prestasi mahasiswa dan lulusan yang baik dan memuaskan.

\section{Kesimpulan :}

Berdasarkan hasil penelitian maka dapat disimpulkan bahwa : 1). Motivasi belajar secara parsial berpengaruh positif terhadap prestasi belajar yang ditunjukkan oleh nilai $\mathrm{r}$ sebesar 0.682 yang berarti hubungan diantara keduanya kuat; 2). Metode pembelajaran secara parsial berpengaruh positif terhadap prestasi belajar yang ditunjukkan oleh nilai $r$ sebesar 0,458 yang berarti hubungan diantara keduanya sangat kuat; dan 3). Secara simultan variabel kemampuan pengajar dan media pembelajaran memiliki pengaruh yang signifikan terhadap kepuasan warga belajar yang ditunjukkan oleh nilai $r$ sebesar 0,687 yang berarti hubungan diantara keduanya sangat kuat. Sedangkan nilai koefisien determinasi R square sebesar 0, 4719 yang artinya bahwa variasi dari semua variabel bebas yaitu motivasi belajar dan metode belajar dapat menerangkan variabel prestasi mahasiswa sebesar 47,19 \%, sedangkan sisanya sebesar $52,81 \%$ diterangkan oleh variabel lain yang tidak diajukan dalam penelitian ini.

\section{Saran}

Berdasarkan hasil penelitian maka disampaikan saran sebagai berikut : 1). Perlunya memberikan motifasi untuk meningkatkan dorongan minat belajar mahasiswa dalam bentuk dorongan belajar dari dalam dirinya sendiri serta mendorong mahasiswa agar selalu bertanya dan mencari referensi saat sulit memahami materi yang nilainya di bawah nilai rata-rata; 2). Perlunya memberikan motifasi untuk meningkatkan dorongan metode belajar mahasiswa dalam bentuk system belajar yang serius tapi menyenangkan, memaksimalkan penggunaan system belajar berbasis internet dan menanamkan perkembangan pesat dalam dunia akuntansi yang nilainya di bawah nilai rata-rata; dan 3). Perlunya memberikan motifasi untuk meningkatkan dorongan prestasi belajar mahasiswa dalam bentuk dasar-dasar dengan perasaan puas dan kebanggaan tersendiri dalam penyelesaian soal akuntansi yang nilainya di bawah nilai rata-rata

\section{DAFTAR PUSTAKA}

Adrian. 2004. Metode Mengajar Berdasarkan Tipologi Belajar Siswa.

Azwar. Saifudin. 2003. Metode Penelitian. Yogyakarta: Pustaka Pelajar.

Dewi, E. R. 2009. Perbedaan Hasil Belajar Psikomotorik Penggunaan Metode Demonstrasi dan Metode Audiovisual pada Pembelajaran Senam Hamil Program 
Studi D IV Kebidanan Fakultas Kedokteran Universitas Sebelas Maret Surakarta: Program Studi D IV Kebidanan Fakultas Kedokteran Universitas Sebelas Maret Surakarta. Karya Tulis Ilmiah

Fathimah. Fithria N. 2008. Hubungan Antara Kedisiplinan Belajar dengan Prestasi Belajar Mahasiswa Kebidanan di AKBID Mitra Husada Karanganyar. Surakarta: Program Studi D IV Kebidanan Fakultas Kedokteran Universitas Sebelas Maret Surakarta. Karya Tulis Ilmiah

Furchan. 2007. Pengantar Penelitian dalam Pendidikan. Yogyakarta: Pustaka Pelajar

Hadis. Abdul. 2008. Psikologi Dalam Pendidikan. Bandung: Alfabeta

Iskandar. 2009. Psikologi Pendidikan Sebuah Orientasi Baru. Jakarta: Gaung Persada Press

Kasijan. 1984. Psikologi Pendidikan: Buku 1. Surabaya: PT Bina Ilmu .

Muchicth, Saekhan. 2008. Penbelajaran Konstektual. Semarang: Rasail Media Group .

Prawiradilaga, D S. 2008. Prinsip Disain Pembelajaran. Jakarta: Kencana.

Ridwan. 2008. Ketercapaian Prestasi Belajar. Didapat dari Dunia Ilmu.htm: Tanggal 10 September 2009

Ropitasari. 2009. Pengaruh Persepsi dan Motivasi terhadap Prestasi Belajar di Ujian akhir Program pada Mahasiswa Diploma IV Kebidanan Universitas Sebelas Maret Surakarta. Tesis: Program Pasca Sarjana magister Kedokteran Keluarga UNS
Roestiyah. 2005. Strategi Belajar Mengajar. Jakarta: PT Rineka Cipta.

Sanjaya. Wina. 2009. Strategi Pembelajaran Berorientasi Standar Proses Pendidikan. Jakarta: Kencana prenada Media Group.

Sukmadinata. Nana. 2004. Landasan Psikologi Proses Pendidikan. Bandung: PT Remaja Rosdakarya

Slameto. 2003. Belajar dan Faktor-Faktor yang Mempengaruhinya. Edisi Revisi. Jakarta: PT Rineka Cipta.

Sugiyono. 2008. Metode Penelitian Pendidikan. Pendekatan Kuantitatif, Kualitatif, dan R\&D. Bandung: Alfabeta

Suwarnisih. 2009. Perbedaan Metode Demonstrasi dan Penuntun Belajar Job Sheet terhadap Prestasi Belajar Partograf pada Mahasiswa Kebidanan Ditinjau dari Motivasi Mahasiswa. Tesis: Program Pasca Sarjana magister Kedokteran Keluarga UNS

Syah, Muhibbin. 2008. Psikologi Pendidikan dengan Pendekatan Baru. Bandung: PT Remaja Rosdakarya

Uno. Hamzah. 2008. Teori Motivasi dan Pengukurannya. Jakarta: Bumi Aksara

Yamin. Martinis. 2008. Desain Pembelajaran Berbasis Tingkat Satuan Pendidikan. Jakarta: Gaung Persada Press . 2009. Strategi Pembelajaran Berbasis Kompetensi. Jakarta: Gaung Persada Press

Winkel. WS. 2005. Psikologi Pengajaran. Yogyakarta: Media Abadi 